This is an Accepted Manuscript of an article published by Taylor \& Francis in Journal of Strategic Marketing in 2016, available online:

http://www.tandfonline.com/10.1080/0965254X.2016.1182576 


\title{
Marketing education and the employability challenge
}

\author{
Deborah Anderson ${ }^{1}$ and Rebecca Lees \\ ${ }^{a}$ Kingston Business School Kingston University, Kingston upon Thames, UK; \\ ${ }^{\mathrm{b}}$ Kingston Business School Kingston University, Kingston upon Thames, UK
}

\begin{abstract}
A major external challenge faced by UK higher education institutions is employability. For some academics, this poses a challenge and many feel it is not their role to help students acquire the generic employability attributes required in the workplace. In this paper, we demonstrate how innovative teaching practice at a UK Business School has ensured the development of good marketing subject learning, whilst at the same time has provided students with an opportunity to acquire generic employability attributes. This has been achieved by approaching an academic staple: the literature review as a series of well-designed tasks in which students learn through participation in rather than individually. The approach is based on a social practice framework and contributes to assertions in the literature good learning can lead to good employability.
\end{abstract}

Keywords: employability, literature review, social practice, participative learning

\section{Introduction}

The modern marketing education environment is characterised by constant change, with both internal and external factors creating seemingly endless challenges for marketing academics. A major external challenge faced by all UK higher education institutions (HEI's) is employability. Since the1997 National Committee of Inquiry into Higher Education (NCIHE, and often referred to as the Dearing Report), subsequent government papers have emphasised the role of HEI's in developing graduates who are 'employable' and who possess the skills and attributes required by industry. For some academics, this poses a challenge and many feel it is not their role to help students acquire generic employability attributes (Barrie, 2007). Nonetheless, employability has become a key indicator in higher education and one which is difficult to ignore.

In this paper, we draw upon innovative practice at a UK Business School to demonstrate how we can meet the challenge of developing employability skills whilst at the same time retaining rigorous academic standards. We will explain how good marketing understanding can be developed by engaging students in a series of social practices linked to an individual academic task: the writing of a literature review. In so doing we aim to demonstrate to those staff who might reject employability as part of their remit that in fact 'good subject matter understanding is compatible with employability policies, and that employability and good learning are highly compatible' ( Knight and Yorke, 2003, p.8).

\section{Employability}

Employability has been on the UK higher education agenda for a number of years, noticeably since the 1997 Dearing Report, although even earlier references can be found in the 1963

\footnotetext{
${ }^{1}$ Corresponding author: D.anderson@kingston.ac.uk
} 
Robbins report (Committee on Higher Education, 1963). More recently employability was highlighted in the Browne report on student funding in 2010 in which the performance of UK higher education institutions was criticised (Andrews and Russell, 2012). In particular it was noted that analysis by the UK Commission on Employability and Skills (2009) suggested that 'the higher education system does not produce the most effective mix of skills to meet business needs' (2009, p.23). As recently as 2013, government reports were still emphasising the need for graduates to have skills beyond those normally developed as part of their degree (Willetts, 2013). With such heavy interest at government level, HEI's have had no choice: employability is firmly on the UK higher education agenda.

The notion of employability is contested and tensions focus largely on whether it can be seen in terms of the rate of graduate employment (a measure often used in league tables and in government reports) or the fitness for graduate employment (Harvey, 2005; Knight and Yorke, 2003; Yorke and Knight, 2007). Harvey (2005) suggests that employability is not simply about getting a job, but instead is about learning, proposing less emphasis on 'employ' and more on 'ability'. In this view, employment itself is a by-product of an enabling process. Such an enabling process involves the development of skills and competences but also broader-based qualities relating to values, intellectual rigour and engagement (Pegg, Waldcock, Hendy-Isaac and Lawton, 2012).

The skills, qualities and attributes required of today's graduates vary include the very basic 'key skills' identified in the Dearing report (1997): communication, numeracy and IT. These have often underpinned course and curriculum design and mapping exercises have ensured that new courses have provided an opportunity for students to develop these key skills. At a higher level, generic graduate attributes have been seen as going beyond subject expertise and technical skills. Often these are agreed at University level in an attempt to ensure common understanding of what a student should be developing during their time at University (Barrie, 2007).

Research amongst employers suggested that knowledge, intellect, willingness to learn, selfmanagement skills, teamwork and inter-personal skills were attributes sought by employers. Knight and Yorke (2003) draw upon research by the Association of Graduate Recruiters which suggests that at the time when employability was starting to be discussed more frequently, it comprised 'career management skills and effective learning skills: self-awareness, selfpromotion, exploring and creating opportunities, action planning, networking, matching and decision-making, negotiation, political awareness, coping with uncertainty, development focus, transfer skills and self-confidence' (Knight and Yorke, 2003, p.6). Other attributes identified by Knight and Yorke (2003) include the 'ability to work under pressure, commitment, working varied hours, dependability, imagination/creativity, getting on with people and willingness to learn' (Knight and Yorke, 2003, p.7). Research specifically into employment in marketing suggests a distinction between the technical, practical skills, conceptual skills and more generic skills such as oral and written communication and critical thinking skills (Schlee and Harich, 2010).

Further developments in employability have confirmed that rather than a simple set of skills, it encompasses a wider set of abilities related to reflection and articulation of learning (Pegg et al., 2012). Models have emerged which aim to explain what employers are looking for as a way of informing employability development. For example, Knight and Yorke's (2003) 'USEM' model includes identifying understanding, skills, efficacy beliefs and meta-cognition as key elements of 
employability. Reflection and meta-cognition also recommended by Junghagen (2005) who suggests them as ways of achieving the higher order thinking tasks sought by employers. Cole and Tibby (2013) highlight the importance of reviewing not only what is taught on a programme but also how it is taught, with an emphasis on developing students' abilities to recognise their own achievements: personally, academically and in relation to career development. Developing this further, Dacre Pool and Sewell (2007) propose a practical model of employability to highlight how aspects of a student's university experience could combine to make them more employable. Their model suggests that through reflection and evaluation, students are able to develop self-efficacy, self-esteem and self-confidence, leading to an increase in their employability.

With such a focus on the development of generic attributes and skills and less emphasis on discipline knowledge, it is unsurprising that academics have not always felt positively about taking responsibility for employability. Barrie (2007) for example found that some academics in his study saw no place for employability in their courses, with a third of the participants viewing generic attributes as 'relatively unimportant additive outcomes, taught as a supplement to the more important discipline content' (Barrie, 2007, p.454).

Knight and Yorke (2003) however already had a counter argument in place for such a view. Their claim is that good learning leads to good employability. By developing good subject understanding and study habits, students will develop generic attributes which will enhance their employability. They do however acknowledge that this requires a re-think for academics to ensure that students are taught in an environment which fosters such development. In order to persuade academics to accept such a re-think, they propose that curriculum processes are prioritised rather than employability itself.

In summary, although developing employability skills is not always high on the priority list for academics, evidence from the literature suggests that good learning is compatible with the development of generic employability skills and attributes. In the next section we will discuss an academic staple, the literature review, then go to demonstrate a teaching approach in which the literature review assignment can provide a vehicle for developing both good subject knowledge and employability attributes.

\section{The literature review as a form of assessment}

Marketing courses typically include a range of assessments, some very practical such as developing new product development plans and some very theoretical, such as essays. Often, students will be tasked with writing a literature review, sometimes as part of a dissertation or extended project. This is generally accepted to be a way of establishing the theoretical framework for research, drawing upon both conceptual and empirical studies (Gordon and Stewart, 2002; Boote and Beile, 2005; Green and Bowser, 2006 ). The literature review can also serve several additional purposes. Initially a review of existing understanding can help identify the potential knowledge contribution for a study, helping to formulate a research problem. Reviewing the methodologies in a field of enquiry can provide guidance in research design, identifying the different possible directions (Merriam, 1998). A review of the literature can help to define the scope of the research (Boote and Beile, 2005) and can establish a collective understanding of what has been done before. Indeed, the literature review is accepted to be an essential element of becoming an 'expert in the field' (Hart, 2003, p.1). Far from being an 
appendage, or an ad-hoc 'add-on' (Gordon and Stewart, 2002), a review of literature ensures that the researcher appreciates the debates in a field, helping to develop an argument and an explanation of how they are going to extend existing knowledge (Zorn and Campbell, 2006). There appears to be no disagreement amongst scholars on the importance of the literature review for academic purposes. What appears to be missing is any appreciation of the value of the literature review for developing skills which will be valuable in the workplace.

The next section will draw upon an innovative case study of teaching practice at a UK Business School where the literature review has been broken down into a series of tasks or 'social practices' which, although initially developed to help the process of writing the review, have led to improved subject learning and in turn have contributed to the development of generic employability attributes amongst both postgraduate and undergraduate marketing and business students.

\section{Case study: the literature review as a series of social practices}

In this case study, a literature review-based assignment is briefed at the beginning of the semester and students typically have nine weeks in which to complete their work. Although the assignment is a traditional review of academic papers, as a standalone piece of work (and not as part of a dissertation) it is presented to the students either as an 'industry briefing paper' or a 'marketing insights paper'. The purpose for both versions is for students to draw together current research on a topic with a view to keeping practitioners up to date. Three topic choices are offered, covering contemporary marketing issues such as viral marketing, product placement and location-based marketing. During the nine week period, three specific tasks are completed: 'Experts and Novices', 'The Mini Conference' and 'Review and Reflect (each will be explained in detail below). Each task requires students share their work in progress with peers, drawing upon each other to develop their subject knowledge and their academic skills. We will demonstrate how such improved academic practice in turn leads to the development of generic employability attributes.

Table 1: Literature review timeline

\begin{tabular}{|l|l|l|}
\hline & Individual tasks & Social practice tasks \\
\hline Week 1 & $\begin{array}{l}\text { Literature review assignment (in the } \\
\text { form of an industry briefing paper or } \\
\text { a marketing insights paper) briefed: } \\
\text { choice of 3 contemporary marketing } \\
\text { topics }\end{array}$ & \\
\hline Week 2-3 & $\begin{array}{l}\text { Individual research: reading of 5 } \\
\text { journal articles in preparation for an } \\
\text { Experts and Novices session }\end{array}$ & \\
\hline Week 4,5,6 & $\begin{array}{l}\text { Individual work: further research, } \\
\text { further reading and write-up of } \\
\text { literature review }\end{array}$ & $\begin{array}{l}\text { Experts and Novices sessions; topics 1,2 and } \\
\text { Mini Conference associated with each topic }\end{array}$ \\
\hline Week 7-8 & \multicolumn{2}{|l|}{} \\
\hline Week 9 & \multicolumn{2}{|l|}{ Review and Reflect and submission } \\
\hline
\end{tabular}


The incorporation of a series of participative tasks for learning is based on the notion of communities of practice. These are defined as 'a set of relations among persons, activity, and world, over time and in relation with other tangential and overlapping communities of practice' (Lave and Wenger, 1991, p.98). Within a community of practice, Lave and Wenger (1991) see the participants sharing understanding about what they are doing and what that means in their lives and for their communities (Lave and Wenger, 1991). They propose that rather than simply acquiring new skills and knowledge, participants' learning involves moving towards full participation in a community's social and cultural practices. This could include becoming familiar with the language used and the acceptable types of interaction. In this instance, working with other students on the series of tasks enables students to share understanding about the literature review and become familiar with the cultural practices associated with its development.

Communities of practice are underpinned by social practice theory (Lave and Wenger, 1991; Wenger, 1998) which emphasises the benefits of learning in a participative way rather than in isolation. Based on an approach developed by Vygotsky (1987) learning in this manner foregrounds the participation and social aspects of learning rather than focusing on the individual as a receptacle of knowledge.

It is worth noting that, with the exception of Freer and Barker (2008) and Gordon and Stewart (2002), advice on writing a literature review assumes that individuals will work alone or at most will engage with peers in a virtual classroom or in the review of their work. This is in contrast to the number of academic studies which are co-authored by teams of academics. It appears that whilst academics are keen to work collaboratively, we are less happy to allow students to do the same. Whilst the detailed reasons for this are beyond the scope of this paper, Burdett (2007) has suggested that academics can be wary of using group-work for credit-bearing assessment, with particularly troublesome aspects of group-work focusing on those which require academic interventions such as resolving disputes and conflict, group members not attending or contributing, domineering students and plagiarism (Burdett, 2007).

\section{Social practice 1: Experts and Novices}

Experts and Novices was originally introduced as an intervention to help masters students develop the critical analytical and synthesis skills required for a strong literature review. It was developed on the principle that by having to discuss early ideas about their work with their peers, students would begin to gain confidence in the critical evaluation needed when reviewing several studies in a topic. Experts and Novices involves nominating some students as 'experts' and some as 'novices' during selected sessions (typically weeks 4,5 and 6) during the nine week period of working on the literature review. Experts are those students who have completed in-depth reading of five journal articles on their chosen topic, whilst novices have just read one journal article or a chapter from the course text. The experts are then responsible for briefing the novices on the topic during the session. Each expert is randomly assigned to two novices and given ten minutes in which to explain their reading. This is then repeated to ensure that all novices are exposed to two experts. During the discussions, experts are expected to highlight areas of consensus and of disagreement in their chosen topic. They are encouraged to explain why one opinion may be more valid than another, based upon their critical analysis of the research used to substantiate such opinions. In the weeks following the Experts and Novices sessions, students 
continue individually with their literature review, drawing upon further sources, often derived from other experts in the session.

Qualitative research in 2011 concluded that students developed critical analysis skills, time management (by having to start an assignment early), listening and presentation skills. Evidence of a growing confidence emerged from the discussions:

I read the five journals, read the textbooks and you know brought out the most important parts of the journals and sort of I don't know I feel like there was actually quite an interesting debate going on, people were asking me and I could actually answer them and things like that..

(Marketing postgraduate student).

I think the thing is you can test yourself whether you have understood it when the novice asks very interesting and clever questions, you can then think oh well I haven't really got behind that yet and I need to focus a little bit more... (Marketing postgraduate student).

Perceived benefit in the sharing of sources was also apparent:

The other thing I found very useful was actually sharing the best journals because when I get to do my literature review I did have a couple of journals that I really liked and then my talking to other people and they started sharing.......so I got actually the best ones and that's why I could argue about my topic so I think that was the best part (Marketing postgraduate student).

There was also positive evidence to suggest that the Experts and Novices approach was helpful in developing critical evaluation skills:

I think it's a good way to develop critical evaluation because you get other ideas... you think in a different way because you get a new idea and have to evaluate it and maybe you didn't think about it before (Marketing postgraduate student).

\section{Social practice 2: The Mini Conference}

The Mini Conference was developed as a distinct activity to follow on from the Experts and Novices sessions as a way of ensuring full exposure of all ideas and themes discussed. Previous research (Anderson, 2011) had identified that students who spoke to weaker experts felt that they were missing out on some of the knowledge being shared in the classroom. In brief, in the Mini Conference experts are grouped together in groups of four to five. Their brief is to develop a conference presentation on 'Contemporary Developments' in their expert topic (e.g., location based advertising or product placement). Groups have an hour to prepare and they are required to produce a logical, coherent presentation of their collective ideas. Meanwhile, the novices are tasked with preparing a presentation in which they apply their new learning to a practical business scenario. Presentations can use as much or as little technology as the students choose, and last no more than ten minutes. During the Mini Conference, expert presentations are alternated with novice ones, giving both theoretical and practical aspects to the Mini Conference. On a practical note, this combination of Experts and Novices and the Mini Conference requires a session of three hours, although it would be possible to run Experts and Novices in one shorter session, followed by a Mini Conference in a separate, subsequent session

In addition to the presentation skills, this task also requires listening, synthesising and negotiation skills. Individually each expert will have drawn together several ideas which may or 
may not overlap with other students' findings. By having to combine their new knowledge under pressure into a brief summary, students are obliged to discuss, listen and argue for the inclusion of their findings. At this stage they are also able share resources, identifying particularly strong papers for their own literature reviews.

Initial evaluation of the Mini Conference has taken place using short answer questions. Although not conclusive, initial impressions are that the practice has been received positively, in particular as a way of consolidating all the new knowledge from the session.

The conferences were interesting since the experts also gave more information as well as the novices. This was good since people also understood the theory and literature as well (Final year Business undergraduate student).

I think the structure of the three sessions was good and I liked the concept of presenting because it shows us what we have learnt throughout the sessions (Final year Business undergraduate student).

There was also a feeling that the mini conference provided reassurance that students were on the right track

After completing the mini conference, I felt more confident to continue with my research and had new knowledge of industry examples and academic papers that I could use (Final year Business undergraduate student).

\section{Social practice 3: Review and Reflect}

The final social practice in the literature review development is a Review and Reflect exercise which takes place just prior to submission of the literature review assignment. In small groups, students are invited to read each other's work and discuss aspects such as the content, the relative merits of the sources used and the skills developed when completing the work. Discussions last an hour, with two separate groups and then students are invited individually to write a reflective summary of their discussions.

The main purpose of this final social practice is to ensure that students become aware of their own achievements and skills developed as part of the assignment. The requirement to reflect on the relative merit of journal articles, books and other materials also encourages critical thinking, ensuring that students develop an awareness of the validity of sources.

\section{Discussion}

We argue that by viewing the literature review assignment as a series of social practices, students will not only develop a deeper understanding of their discipline, they will also develop generic attributes which contribute to their employability. By providing new tools and making it easy to discuss different approaches and share problems (Knight and Yorke, 2003) good learning through participation is achieved. In addition, throughout the three social practices we can see how students are developing the employability attributes and skills identified earlier in the paper. For example, the self-efficacy, self-esteem and self-confidence proposed by Dacre Pool and Sewell (2007) are clearly emerging in Experts and Novices sessions and the Review and Reflect practice provides a further opportunity to reflect on personal achievements. Table 2 below maps out the skills developed during each of the social practices. 
Table 2: Mapping social practice and employability

\begin{tabular}{|l|l|}
\hline & Employability skills developed \\
\hline $\begin{array}{l}\text { Social Practice 1: } \\
\text { Experts and } \\
\text { Novices }\end{array}$ & $\begin{array}{l}\text { Presentation skills; synthesis skills, listening skills, critical analysis, defending an } \\
\text { argument, attention to detail (e.g. referencing); self-management skills, inter- } \\
\text { personal skills } \\
\text { Coping with uncertainty, self-efficacy, self-esteem and self-confidence (Dacre } \\
\text { Pool and Sewell); critical thinking skills (Schlee and Harich, 2010). }\end{array}$ \\
\hline $\begin{array}{l}\text { Social Practice 2: } \\
\text { The Mini } \\
\text { Conference }\end{array}$ & $\begin{array}{l}\text { Presentations and pitches, sharing resources; teamwork; } \\
\text { Self-promotion, negotiation, ability to work under pressure, getting on with } \\
\text { people (Knight and Yorke, 2003) oral communication (Schlee and Harich, 2010) }\end{array}$ \\
\hline $\begin{array}{l}\text { Social Practice 3: } \\
\text { Review and Reflect }\end{array}$ & $\begin{array}{l}\text { Self-awareness (Knight and Yorke, 2003); recognition of their own achievements } \\
\text { (Cole and Tibby, 2013); self-efficacy, self-esteem and self-confidence (Dacre } \\
\text { Pool and Sewell, 2007); metacognition (Junghagen, 2005; Pegg } \text { et al., 2012; } \\
\text { Yorke and Knight, 2007); critical thinking skills (Schlee and Harich, 2010) }\end{array}$ \\
\hline
\end{tabular}

The original concept of communities of practice developed by Lave and Wenger (1991) and outlined above did not include a formalised structure; indeed development of communities of practice was seen as a phenomenon which occurred outside the formal hierarchies of organisations. The inclusion of a series of "guided" social practice could be considered as a 'facilitated' community of practice in which members are encouraged to develop a shared domain of interest and develop relationships through social interaction and activity (Jakovljevic, Buckley and Bushney, 2013). Indeed, as the learning which takes place in such communities has been positively viewed, we have seen a move towards academics creating communities of practice for their students (Hutchinson et al., 2015). In this way, we can see that academics are providing the learning environments advocated by Knight and Yorke (2003) in which students are offered opportunities to work together on problems and improve their understanding together (Knight and Yorke, 2003).

\section{Conclusions}

In this paper we have demonstrated that individual academic work such as the writing of a literature review can be an excellent vehicle for the development of employability skills if approached as a series of well-designed tasks in which students engage with others and learn through a social practice based approach rather than individually. Our approach is based on a social practice framework and contributes to Knight and Yorke's (2003) assertion that by planning good learning environments, we can provide many useful opportunities for students to mix with other to work jointly on tasks. From the academic's point of view, this does require some curriculum planning in advance, with relevant and timely tasks built in to the assessment process. However, the benefits in terms of good learning as well as good employability suggest the approach is worth the investment and should not challenge academics' attachment to their disciplines.

\section{Implications for marketing education}

Although the example has been a literature review based assignment, the approach could also be used for other forms of assessment such as traditional essays. For example, rather than Experts and Novices, students could be set tasks such as a one page plan to be discussed with peers prior 
to setting out fully on the essay task. This would be an opportunity to discuss ideas, develop meanings, share resources and check that an appropriate direction had been chosen.

\section{References}

Anderson, D. (2011) 'Experts and Novices': can participative approaches to learning help the lonely academic writer? In: Patterson, A. and Oakes, S. (eds) Proceedings of the Academy of Marketing Conference 2011: Marketing Fields Forever, Academy of Marketing, Liverpool.

Andrews, G. and Russell, M. (2012) Employability skills development: strategy, evaluation and impact. Higher Education, Skills and Work-based Learning. Vol. 2, No. 1, pp33-44.

Barrie, S.C. (2007) A conceptual framework for the teaching and learning of generic graduate attributes. Studies in Higher Education. Vol. 32, No. 4, pp439-458.

Boote, D.N. and Beile, P. (2005) Scholars before researchers: on the centrality of the dissertation literature review in research preparation. Educational Researcher. Vol. 34, No. 6, pp3-15.

Browne Report (2010) Securing a sustainable future in higher education. London: Department of Business Innovation and Skills.

Burdett, J. (2007). Degrees of separation - balancing intervention and independence in group work assignments. The Australian Educational Researcher, Vol. 34, No.1,pp55-71.

Committee on Higher Education (1963) Higher Education: Report of the Committee appointed by the Prime Minister under the chairmanship of Lord Robbins, 1961-63: 'The Robbins Report'. London: Her Majesty's Stationery Office.

Cole, D. \& Tibby, M. (2013) Defining and developing your approach to employability, a framework for higher education institutions. York Higher Education Academy.

Dacre Pool, L. \& Sewell, P. (2007) The key to employability. Developing a practical model of graduate employability. Education and Training, Vol. 49, No. 4, pp277-289.

Freer, P.K. and Barker, A. (2008) An instructional approach for improving the writing of literature reviews. Journal of Music Teacher Education. Vol. 17, No. 2.

Gordon, W.F. and Stewart, G.D.J. (2002) Report on a Private Project: using a virtual classroom to develop literature review and writing skills. South African Journal of Library and Information Science, Vol. 68, No. 1.

Green, R. And Bowser, M. (2006) Observations from the field: sharing a literature review rubric. Journal of Library Administration. Vol. 45, No. 1, pp185-202.

Harvey, L. (2005) Embedding and integrating employability. New Directions for Institutional Research, No.128, pp13-28.

Hart, C. (2003) Doing a literature review. Sage Publications, London.

Hutchinson, S., Fenton-O’Creevy, M., Goodliff, G., Edwards, D., Hartnett, L., Holti, R., Mackay, 
E., McKeogh, S., Sansayer, P., \& Way, L., (2015). An invitation to a conversation. In Wenger-Trayner, E., Fenton-O’Creevy, M., Kubiak, C., \& Wenger-Trayner, B. (Eds) Learning in Landscapes of Practice, Abingdon, Oxon: Routledge.

Jakovljevic, M., Buckley, S., and Bushney, M. (2013). Forming communities of practice in higher education: A theoretical perspective. In Active Citizenship by Knowledge Management \& Innovation: Proceedings of the Management, Knowledge and Learning International Conference 2013. ToKnowPress, pp. 1107-1119

Junghagen, S. (2005) Working with business and industry to enhance curriculum development and student employability. New Directions for Institutional Research, No.128, pp69-82.

Knight, P.T. \& Yorke, M. (2003) Employability and good learning in Higher Education. Teaching in Higher Education, Vol.8, No. 1, pp3-16.

Lave, J. and Wenger, E. (1991) Situated Learning: legitimate peripheral participation. Cambridge University Press.

Merriam, S.B. (1998) Qualitative research and case study applications in education. Wiley, San Francisco.

National Committee of Inquiry into Higher Education (1997) Higher Education in the Learning Society. HMSO, Norwich.

Pegg, A., Waldcock, J., Hendy-Isaac, S. \& Lawton, R. (2012) Pedagogy for Employability. The Higher Education Academy.

Saunders, M.N.K., Lewis, P. and Thornhill, A. (2012) Research Methods for Business Students. ( $6^{\text {th }}$ ed.) Harlow, UK: FT Prentice Hall.

Schlee, R.P. and Harich, K.R. (2010) Knowledge and skill requirements for marketing jobs in the $21^{\text {st }}$ century. Journal of Marketing Education, Vol 32, No. 3, pp341-352.

Vygotsky, L.S. (1987) Thinking and Speech. Plenum, New York.

Wenger, E. (1998) Communities of Practice: Learning, Meaning and Identity. Cambridge University Press, Cambridge.

Willets, D. (2013) Robbins revisited. Bigger and better Higher Education. London: Social market Foundation.

Yorke, M. \& Knight, P. (2007) Evidence-informed pedagogy and the enhancement of student employability. Teaching in Higher Education, Vol. 12, No.2, pp157-170.

Zorn, T. And Campbell, N. (2006) Improving the writing of literature reviews through a literature integration exercise. Business Communication Quarterly. Vol. 69, No. 2, pp 172-183. 
